\title{
Front Matter: Volume 8948
}

, "Front Matter: Volume 8948," Proc. SPIE 8948, Multiphoton Microscopy in the Biomedical Sciences XIV, 894801 (27 March 2014); doi:

$10.1117 / 12.2052756$

SPIE. Event: SPIE BiOS, 2014, San Francisco, California, United States 


\title{
PROGRESS IN BIOMEDICAL OPTICS AND IMAGING
}

\section{Multiphoton Microscopy in the Biomedical Sciences XIV}

\author{
Ammasi Periasamy \\ Peter T. C. So \\ Karsten König \\ Editors
}

2-4 February 2014

San Francisco, California, United States

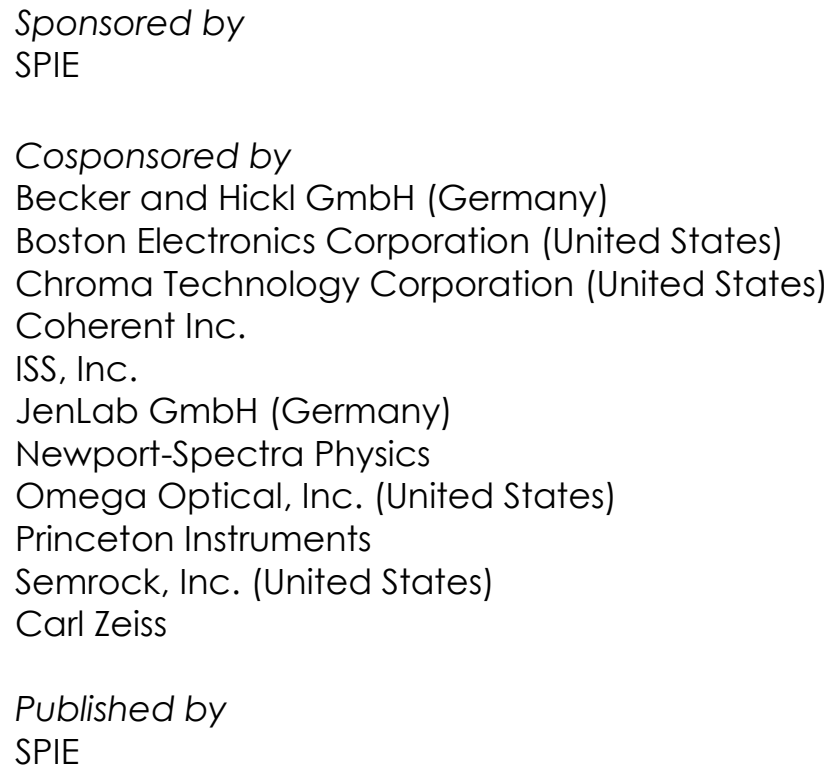


The papers included in this volume were part of the technical conference cited on the cover and title page. Papers were selected and subject to review by the editors and conference program committee. Some conference presentations may not be available for publication. The papers published in these proceedings reflect the work and thoughts of the authors and are published herein as submitted. The publisher is not responsible for the validity of the information or for any outcomes resulting from reliance thereon.

Please use the following format to cite material from this book:

Author(s), "Title of Paper," in Multiphoton Microscopy in the Biomedical Sciences XIV, edited by Ammasi Periasamy, Peter T. C. So, Karsten König, Proceedings of SPIE Vol. 8948 (SPIE, Bellingham, WA, 2014) Article CID Number.

ISSN: 1605-7422

ISBN: 9780819498618

Published by

SPIE

P.O. Box 10, Bellingham, Washington 98227-0010 USA

Telephone +1 3606763290 (Pacific Time) · Fax +1 3606471445

SPIE.org

Copyright (C) 2014, Society of Photo-Optical Instrumentation Engineers.

Copying of material in this book for internal or personal use, or for the internal or personal use of specific clients, beyond the fair use provisions granted by the U.S. Copyright Law is authorized by SPIE subject to payment of copying fees. The Transactional Reporting Service base fee for this volume is $\$ 18.00$ per article (or portion thereof), which should be paid directly to the Copyright Clearance Center (CCC), 222 Rosewood Drive, Danvers, MA 01923. Payment may also be made electronically through CCC Online at copyright.com. Other copying for republication, resale, advertising or promotion, or any form of systematic or multiple reproduction of any material in this book is prohibited except with permission in writing from the publisher. The CCC fee code is $1605-7422 / 14 / \$ 18.00$.

Printed in the United States of America.

Publication of record for individual papers is online in the SPIE Digital Library.

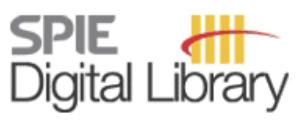

SPIEDigitalLibrary.org

Paper Numbering: Proceedings of SPIE follow an e-First publication model, with papers published first online and then in print and on CD-ROM. Papers are published as they are submitted and meet publication criteria. A unique, consistent, permanent citation identifier (CID) number is assigned to each article at the time of the first publication. Utilization of CIDs allows articles to be fully citable as soon as they are published online, and connects the same identifier to all online, print, and electronic versions of the publication. SPIE uses a six-digit CID article numbering system in which:

- The first four digits correspond to the SPIE volume number.

- The last two digits indicate publication order within the volume using a Base 36 numbering

system employing both numerals and letters. These two-number sets start with 00, 01, 02, 03, 04, $05,06,07,08,09,0 A, 0 B \ldots 0 Z$, followed by 10-1Z, 20-2Z, etc.

The CID Number appears on each page of the manuscript. The complete citation is used on the first page, and an abbreviated version on subsequent pages. Numbers in the index correspond to the last two digits of the six-digit CID Number. 


\section{Contents}

ix Conference Committee

xi Introduction

\section{KEYNOTE SESSION}

894802 Adaptive optics from microscopy to nanoscopy (Keynote Paper) [8948-1]

B. R. Patton, D. Burke, M. J. Booth, Univ. of Oxford (United Kingdom)

894804 Quantitative multiphoton imaging (Keynote Paper) [8948-3]

K. König, JenLab GmbH (Germany) and Saarland Univ. (Germany); M. Weinigel, JenLab GmbH (Germany); H. G. Breunig, A. Uchugonova, JenLab GmbH (Germany) and Saarland Univ. (Germany)

\section{SHG/THG MICROSCOPY I}

894807 Non-linear imaging and characterization of atherosclerotic arterial tissue using combined two photon fluorescence, second-harmonic generation and CARS microscopy [8948-6] R. Cicchi, National Institute of Optics, CNR (Italy) and European Lab. for Non-Linear Spectroscopy (Italy); C. Matthäus, T. Meyer, Institute of Photonic Technology (Germany); A. Lattermann, Jena Univ. Hospital, Friedrich-Schiller Univ. (Germany); B. Dietzek, Institute of Photonic Technology (Germany) and Institute of Physical Chemistry and Abbe Ctr. of Photonics, Friedrich-Schiller Univ. (Germany); B. R. Brehm, Catholic Clinic, Koblenz (Germany); J. Popp, Institute of Photonic Technology (Germany) and Institute of Physical Chemistry and Abbe Ctr. of Photonics, Friedrich-Schiller Univ. (Germany); F. S. Pavone, National Institute of Optics, CNR (Italy), European Lab. for Non-linear Spectroscopy (Italy), and Univ. of Florence (Italy)

894808 Second-harmonic generation reveals a relationship between metastatic potential and collagen fiber structure [8948-7]

K. A. Burke, R. P. Dawes, Univ. of Rochester (United States); M. K. Cheema, State Univ. of New York at Stony Brook (United States); S. Perry, E. Brown III, Univ. of Rochester (United States)

894809 The study of radiation-induced damage and remodeling of extracellular matrix of rectum and bladder by second-harmonic generation microscopy [8948-8]

M. V. Kochueva, Nizhny Novgorod State Medical Academy (Russian Federation); E. A. Sergeeva, Institute of Applied Physics (Russian Federation); N. Yu. Ignatjeva, Lomonosov Moscow State Univ. (Russian Federation); O. L. Zakharkina, Institute of Laser and Information Technologies (Russian Federation); S. S. Kuznetzov, E. B. Kiseleva, Nizhny Novgorod State Medical Academy (Russian Federation); K. V. Babak, N.I. Lobachevsky State Univ. of Nizhni Novgorod (Russian Federation); V. A. Kamensky, Institute of Applied Physics (Russian Federation); A. V. Maslennikova, Nizhny Novgorod State Medical Academy (Russian Federation) and N.I. Lobachevsky State Univ. of Nizhni Novgorod (Russian Federation) 
8948 OA Towards a compact fiber laser for multimodal imaging [8948-9]

B. Nie, I. Saytashev, M. Dantus, Michigan State Univ. (United States)

\section{SHG/THG MICROSCOPY II}

$8948 \mathrm{OB}$ In vivo time-lapse imaging of skin burn wound healing using second-harmonic generation microscopy [8948-81]

T. Yasui, Univ. of Tokushima (Japan) and Osaka Univ. (Japan); R. Tanaka, Osaka Univ.

(Japan); E. Hase, Univ. of Tokushima (Japan); S. Fukushima, T. Araki, Osaka Univ. (Japan)

\section{TECHNOLOGY DEVELOPMENT AND APPLICATIONS I}

8948 ol Exploring the brain on multiple scales with correlative two-photon and light sheet microscopy (Invited Paper) [8948-16]

L. Silvestri, A. L. Allegra Mascaro, I. Costantini, European Lab. for Non-linear Spectroscopy (Italy); L. Sacconi, National Institute of Optics, CNR (Italy) and European Lab. for Non-linear Spectroscopy (Italy); F. S. Pavone, European Lab. for Non-linear Spectroscopy (Italy), National Institute of Optics, CNR (Italy), Univ. of Florence (Italy), and International Ctr. for Computational Neurophotonics (Italy)

BIOMEDICAL APPLICATIONS OF COHERENT RAMAN I

8948 OR Broadband hyperspectral coherent anti-Stokes Raman scattering microscopy for stain-free histological imaging with principal component analysis [8948-25]

J. XU, B. Guo, K. K. Y. Wong, K. K. Tsia, The Univ. of Hong Kong (Hong Kong, China)

\section{BIOMEDICAL APPLICATIONS OF COHERENT RAMAN II}

8948 OU CARS microscopy of Alzheimer's diseased brain tissue (Invited Paper) [8948-28] A. Enejder, J. Kiskis, H. Fink, L. Nyberg, Chalmers Univ. of Technology (Sweden); J. Thyr, K-Analys AB (Sweden); J.-Y. Li, Wallenberg Neuroscience Ctr., Lund Univ. (Sweden)

8948 OV Simultaneous stimulated Raman scattering and higher harmonic generation imaging for liver disease diagnosis without labeling [8948-29]

J. Lin, Z. Wang, W. Zheng, Z. Huang, National Univ. of Singapore (Singapore)

\section{COHERENT RAMAN TECHNICAL DEVELOPMENT I}

894812 Multimodal microscopy with high resolution spectral focusing CARS [8948-36]

T. Baldacchini, R. Zadoyan, Newport Corp. (United States) 
894814 Fiber bundle based endomicroscopy prototype with two collection channels for simultaneous coherent anti-Stokes Raman scattering and second harmonic generation imaging [8948-38]

Z. Liu, Beijing Institute of Technology (China) and Weill Cornell Medical College (United States); Z. A. Satira, Weill Cornell Medical College (United States) and Rice Univ. (United States); X. Wang, X. Xu, X. Chen, K. Wong, Weill Cornell Medical College (United States); S. Chen, J. Xin, Beijing Institute of Technology (China); S. T. C. Wong, Weill Cornell Medical College (United States) and Rice Univ. (United States)

894815 High-performance fiber parametric oscillator for coherent Raman microscopy [8948-39] E. S. Lamb, S. Lefrancois, Cornell Univ. (United States); M. Ji, Harvard Univ. (United States); W. J. Wadsworth, Univ. of Bath (United Kingdom); X. S. Xie, Harvard Univ. (United States); F. W. Wise, Cornell Univ. (United States)

894816 Tunable dual-wavelength two-picosecond light source for coherent Raman scattering microscopy [8948-40]

I. Rimke, APE GmbH (Germany); G. Hehl, Univ. Stuttgart (Germany); M. Beutler, P. Volz, APE

GmbH (Germany); A. Volkmer, Univ. Stuttgart (Germany); E. Büttner, APE GmbH (Germany)

894817 Fourth-order coherent Raman microspectroscopy for detection of material symmetry [8948-41]

M. Hashimoto, H. Kanoh, H. Niioka, T. Araki, Osaka Univ. (Japan)

894819 Multiphoton imaging of biological samples during freezing and heating [8948-43]

H. G. Breunig, JenLab GmbH (Germany) and Saarland Univ. (Germany); A. Uchugonova, JenLab GmbH (Germany); K. König, JenLab GmbH (Germany) and Saarland Univ. (Germany)

\section{FLIM/FRET/FCS I}

8948 1D High-sensitivity single molecule fluorescence detection using scanning single-molecule counting [8948-47]

M. Yamaguchi, T. Tanabe, H. Nakata, T. Hanashi, K. Nishikawa, K. Hori, S. Kondo, Olympus Corp. (Japan)

\section{FLIM/FRET/FCS II}

$894811 \quad$ Fluorescence lifetime imaging of induced pluripotent stem cells (Invited Paper) [8948-52] A. Uchugonova, Saarland Univ. (Germany) and JenLab GmbH (Germany); A. Batista, Saarland Univ. (Germany); K. König, Saarland Univ. (Germany) and JenLab GmbH (Germany)

$89481 \mathrm{~J} \quad$ Regulatory conformational changes of the $\varepsilon$ subunit in single FRET-labeled FoF 1 -ATP synthase (Invited Paper) [8948-53]

T. M. Duncan, SUNY Upstate Medical Univ. (United States); M. G. Düser, Univ. Stuttgart (Germany); T. Heitkamp, D. G. G. McMillan, M. Börsch, Friedrich-Schiller-Univ. Jena (Germany) 
8948 1K Megapixel FLIM [8948-54]

H. Studier, Becker \& Hickl GmbH (Germany); K. Weisshart, O. Holub, Carl Zeiss Microscopy GmbH (Germany); W. Becker, Becker \& Hickl GmbH (Germany)

$89481 \mathrm{M}$ An automated image processing routine for segmentation of cell cytoplasms in highresolution autofluorescence images [8948-56]

A. J. Walsh, M. C. Skala, Vanderbilt Univ. (United States)

$89481 \mathrm{~N} \quad$ A molecular imaging analysis of C×43 association with Cdo during skeletal myoblast differentiation [8948-57]

D. Nosi, Univ. degli Studi di Firenze (Italy); R. Mercatelli, Istituto dei Sistemi Complessi, CNR (Italy); F. Chellini, Univ. degli Studi di Firenze (Italy); S. Soria, Istituto di Fisica Applicata Nello Carrara, CNR (Italy); A. Pini, L. Formigli, Univ. degli Studi di Firenze (Italy); F. Quercioli, Istituto Nazionale di Ottica, CNR (Italy)

\section{TECHNOLOGY DEVELOPMENT AND APPLICATIONS II}

$89481 Q \quad$ Modulation of the pupil function of microscope objective lens for multifocal multi-photon microscopy using a spatial light modulator [8948-60]

N. Matsumoto, Hamamatsu Photonics K.K. (Japan); S. Okazaki, Hamamatsu Univ. School of Medicine (Japan); H. Takamoto, T. Inove, Hamamatsu Photonics K.K. (Japan); S. Terakawa, Hamamatsu Univ. School of Medicine (Japan)

8948 1R A novel clinical multimodal multiphoton tomograph for AF, SHG, CARS imaging, and FLIM [8948-61]

M. Weinigel, JenLab GmbH (Germany) and Univ. of Technology, Ilmenau (Germany);

H. G. Breunig, K. König, JenLab GmbH (Germany) and Saarland Univ. (Germany)

\section{TECHNOLOGY DEVELOPMENT AND APPLICATIONS III}

8948 1T Enhancing stimulated emission-based fluorescence detection with interferometric setup (Invited Paper) [8948-63]

S.-S. M. Chung, J.-H. Deng, P.-L. Lin, F.-J. Kao, National Yang-Ming Univ. (Taiwan)

POSTER SESSION

$894820 \quad$ Multiphoton microscopy for skin wound healing study in terms of cellular metabolism and collagen regeneration (JenLab Young Investigator Award) [8948-71]

G. Deka, National Yang-Ming Univ. (Taiwan); K. Okano, National Chiao Tung Univ. (Taiwan); W.-W. Wu, National Yang-Ming Univ. (Taiwan) and Taipei City Hospital (Taiwan); F.-J. Kao, National Yang-Ming Univ. (Taiwan)

894822 In pixel analysis of molecular structure with Stokes vector resolved second harmonic generation microscopy [8948-73]

N. Mazumder, L. Y. Xiang, J. Qiu, F.-J. Kao, National Yang-Ming Univ. (Taiwan)

894824 Two-photon in vivo imaging of retinal microstructures [8948-75]

A. Schejter, N. Farah, S. Shoham, Technion-Israel Institute of Technology (Israel) 
894825 Super-nonlinear fluorescence microscopy for high-contrast deep tissue imaging [8948-76] L. Wei, X. Zhu, Z. Chen, Columbia Univ. (United States); W. Min, Columbia Univ. (United States) and Kavli Institute for Brain Science (United States)

894826 Multiphoton microscopy using frequency-doubled compact femtosecond erbium-doped fiber laser [8948-77]

L. Huang, S. P. Chong, A. Mills, D. Jones, S. Tang, The Univ. of British Columbia (Canada)

894827 Quantitative determination of maximal imaging depth in all-NIR multiphoton microscopy images of thick tissues [8948-78]

P. Sarder, W. J. Akers, G. P. Sudlow, Washington Univ. School of Medicine (United States);

S. Yazdanfar, GE Global Research (United States); S. Achilefu, Washington Univ. School of Medicine (United States)

894828 Assembly and characterization of a nonlinear optical microscopy for in vivo and ex vivo tissue imaging [8948-79]

S. Pratavieira, H. H. Buzzá, A. E. Jorge, C. Grecco, L. Pires, A. Cosci, V. S. Bagnato,

C. Kurachi, Univ. de São Paulo (Brazil)

8948 2A Evaluating collagen morphology and pathological lipid deposition using multiphoton image statistics [8948-82]

L. B. Mostaço-Guidolin, A. C.-T. Ko, National Research Council Canada (Canada) and Univ. of Manitoba (Canada); F. Wang, H. Tian, Univ. of Manitoba (Canada); M. Hewko, National Research Council Canada (Canada); M. Shiomi, Kobe Univ. School of Medicine (Japan); A. Major, Univ. of Manitoba (Canada); M. G. Sowa, National Research Council Canada (Canada)

8948 2B Detection of back-reflected SHG from corneal histological sections [8948-83]

A. Batista, Univ. de Coimbra (Portugal) and Saarland Univ. (Germany); A. M. Morgado, Univ. de Coimbra (Portugal); K. König, Saarland Univ. (Germany) and JenLab GmbH (Germany)

8948 2D Stepwise multi-photon activation fluorescence reveals a new method of melanoma imaging for dermatologists [8948-85]

Z. Lai, Northeastern Univ. (United States) and Bernard M. Gordon Ctr. for Subsurface Sensing and Imaging System (United States); C. Lian, J. Ma, Brigham and Women's Hospital (United States); J. Yu, Harvard Univ. (United States); Z. Gu, Northeastern Univ. (United States) and Bernard M. Gordon Ctr. for Subsurface Sensing and Imaging System (United States); M. Rajadhyaksha, Memorial and Sloan-Kettering Cancer Ctr. (United States);

C. A. DiMarzio, Northeastern Univ. (United States) and Bernard M. Gordon Ctr. for Subsurface Sensing and Imaging System (United States)

$89482 \mathrm{E}$ Diagnosis of basal cell carcinoma by two photon excited fluorescence combined with lifetime imaging [8948-86]

S. Fan, X. Peng, Shenzhen Univ. (China); L. Liu, Xidian Univ. (China); S. Liu, Y. Lu, The Sixth People's Hospital of Shenzhen (China); J. Qu, Shenzhen Univ. (China)

$89482 \mathrm{~F}$ Simultaneous selective two-photon microscopy using $\mathrm{MHz}$ rate pulse shaping and quadrature detection of the time-multiplexed signal [8948-87]

I. Saytashev, Michigan State Univ. (United States); B. Xu, Biophotonic Solutions, Inc. (United States); M. T. Bremer, Michigan State Univ. (United States); M. Dantus, Michigan State Univ. (United States) and Biophotonic Solutions, Inc. (United States) 
8948 2J In situ dissolution analysis of pharmaceutical dosage forms using coherent anti-Stokes Raman scattering (CARS) microscopy [8948-91]

A. L. Fussell, E. T. Garbacik, Univ. Twente (Netherlands); K. Löbmann, Univ. of Copenhagen (Denmark); H. L. Offerhaus, Univ. Twente (Netherlands); P. Kleinebudde, Heinrich-HeineUniv. Düsseldorf (Germany); C. J. Strachan, Univ. of Helsinki (Finland)

8948 2K Improving multiphoton microscopy using annular beam shaping, focusing on imaging of human skin [8948-92]

J. Borglin, Göteborgs Univ. (Sweden); N. J. Durr, Massachusetts Institute of Technology (United States); S. Guldbrand, Göteborgs Univ. (Sweden); O. Ferhanoglu, The Univ. of Texas at Austin (United States); A.-M. Wennberg, Sahlgrenska Univ. Hospital (Sweden);

D. Hanstorp, Göteborgs Univ. (Sweden); A. Ben-Yakar, The Univ. of Texas at Austin (United States); M. B. Ericson, Göteborgs Univ. (Sweden)

8948 2L Fluorescence lifetime imaging microscopy using a streak camera [8948-93]

L. Liu, Y. Li, L. Sun, Xidian Univ. (China); H. Li, X. Peng, J. Qu, Shenzhen Univ. (China)

$89482 \mathrm{~N}$ Integrated coherent Raman scattering and multiphoton microscopy for label-free imaging of the dentin in the tooth [8948-95]

Z. Wang, W. Zheng, J. Lin, National Univ. of Singapore (Singapore); C.-Y. Hsu, National Univ. of Singapore (Singapore) and National Univ. Health System (Singapore); Z. Huang, National Univ. of Singapore (Singapore)

8948 2T Hyperspectral imaging via spectral interferometric polarised coherent anti-Stokes Raman scattering (Multiphoton Microscopy Best Paper Award) [8948-101]

B. Littleton, T. Kavanagh, F. Festy, D. Richards, King's College London (United Kingdom)

$89482 \mathrm{~V}$ Investigating backward scattered second harmonic generation from various mouse collagen tissues [8948-103]

M. Shen, The Univ. of British Columbia (Canada); Y. Tian, The Univ. of British Columbia (Canada) and The BC Cancer Agency Research Ctr. (Canada); S. P. Chong, The Univ. of British Columbia (Canada); J. Zhao, The BC Cancer Agency Research Ctr. (Canada), The Univ. of British Columbia and Vancouver Coastal Health Research Institute (Canada); $\mathrm{H}$. Zeng, The Univ. of British Columbia (Canada), The BC Cancer Agency Research Ctr. (Canada), and Vancouver Coastal Health Research Institute (Canada); S. Tang, The Univ. of British Columbia (Canada)

$89482 X \quad$ Pulse splitter-based nonlinear microscopy for live-cardiomyocyte imaging [8948-105] Z. Wang, W. Qin, Clemson Univ. (United States); Y. Shao, Shenzhen Univ. (China); S. Ma, Clemson Univ. (United States); T. K. Borg, Medical Univ. Of South Carolina (United States); B. Z. Gao, Clemson Univ. (United States)

Author Index 


\section{Conference Committee}

Symposium Chairs

James G. Fujimoto, Massachusetts Institute of Technology (United States)

R. Rox Anderson, Wellman Center for Photomedicine, Massachusetts General Hospital (United States) and Harvard School of Medicine (United States)

Program Track Chairs

Ammasi Periasamy, University of Virginia (United States)

Daniel L. Farkas, University of Southern California (United States)

Conference Chairs

Ammasi Periasamy, University of Virginia (United States)

Peter T. C. So, Massachusetts Institute of Technology (United States)

Karsten König, Universität des Saarlandes (Germany)

Conference Program Committee

Wolfgang Becker, Becker \& Hickl GmbH (Germany)

Paul J. Campagnola, University of Wisconsin-Madison (United States)

Guy C. Cox, The University of Sydney (Australia)

Alberto Diaspro, Istituto Italiano di Tecnologia (Italy)

Chen-Yuan Dong, National Taiwan University (Taiwan)

Kevin W. Eliceiri, University of Wisconsin-Madison (United States)

Scott Fraser, California Institute of Technology (United States)

Paul M. W. French, Imperial College London (United Kingdom)

Hans C. Gerritsen, Utrecht Universiteit (Netherlands)

Enrico Gratton, University of California, Irvine (United States)

Min Gu, Swinburne University of Technology (Australia)

Stefan W. Hell, Max-Planck-Institut für Biophysikalische Chemie (Germany)

Satoshi Kawata, Osaka University (Japan)

Fu-Jen Kao, National Yang-Ming University (Taiwan)

Arnd K. Krueger, Spectra-Physics, a Newport Corporation Brand

(United States)

Joseph R. Lakowicz, University of Maryland School of Medicine

(United States)

Steve M. McDonald, Coherent, Inc. (United States)

Junle Qu, Shenzhen University (China)

Angelika C. Rueck, Universität Ulm (Germany)

Steven S. Vogel, National Institutes of Health (United States)

Paul W. Wiseman, McGill University (Canada)

X. Sunney Xie, Harvard University (United States) 
Bernhard Zimmermann, Carl Zeiss Jena GmbH (Germany)

Warren R. Zipfel, Cornell University (United States)

\section{Session Chairs}

Keynote Session

Ammasi Periasamy, University of Virginia (United States)

1 SHG/THG Microscopy I

Francesco Saverio Pavone, European Laboratory for Non-linear Spectroscopy (Italy)

2 SHG/THG Microscopy II

Paul J. Campagnola, University of Wisconsin-Madison (United States)

3 Technology Development and Applications I

Aisada Uchugonova, Universität des Saarlandes (Germany)

4 Biomedical Applications of Coherent Raman I

Annika M. Enejder, Chalmers University of Technology (Sweden)

5 Biomedical Applications of Coherent Raman II

Ji-Xin Cheng, Purdue University (United States)

6 Coherent Raman Technical Development I

Eric O. Potma, University of California, Irvine (United States)

7 Coherent Raman Technical Development

Marcus T. Cicerone, National Institute of Standards and Technology (United States)

8 FLIM/FRET/FCS I

Peter T. C. So, Massachusetts Institute of Technology (United States)

9 FLIM/FRET/FCS II

Angelika C. Rueck, Universität Ulm (Germany)

10 Technology Development and Applications II

Fu-Jen Kao, National Yang-Ming University (Taiwan)

11 Technology Development and Applications III

Karsten König, Universität des Saarlandes (Germany)

Poster Session

Holly Aaron, University of California, Berkeley (United States)

Kevin W. Eliceiri, University of Wisconsin-Madison (United States)

Michael Börsch, Friedrich-Schiller-Universität Jena (Germany)

Alberto Diaspro, Istituto Italiano di Tecnologia (Italy)

Chris Xu, Cornell University (United States) 


\section{Introduction}

Multiphoton microscopy has been established as the 3D imaging method of choice for studying biomedical specimens from single cells to whole animals with sub-micron resolution. Two decades have passed since the realization of two-photon laser scanning microscopy. The ever-expanding scope of applications and the continuing instrumental innovations require a forum where new ideas can be exchanged and presented. Our conference at the SPIE Photonics West BiOS 2014 meeting continues to address this need.

This is the 14th year of this conference and we start our conference with three keynote lectures from leaders in the field: Drs. Martin Booth from University of Oxford (United Kingdom), 8948-1: Adaptive optics from microscopy to nanoscopy, Chris Xu, Cornell University (United States), 8948-2: In vivo deep tissue multiphoton imaging, and Karsten König, Saarland University (Germany), 8958-3: Quantitative multiphoton imaging.

For the third year in a row, the conference is extremely pleased to have the JenLab Young Investigator Award, in addition to our regular poster awards. This award is donated by Dr. Karsten König, President and Founder of JenLab GmbH (Germany). The award selection committee includes Drs. Arnd Krueger (NewPort-Spectra Physics), Conor Evans (Harvard University), Paul Campagnola, University of Wisconsin-Madison, and the three conference chairs. The selection process includes the abstract, manuscript and poster presentation. Two finalists are selected for oral presentation after their poster presentation. The two finalists are (1) Dr. Gitanjal Deka, National Yang Ming University (Taiwan), Multiphoton microscopy for skin wound healing study in terms of cellular metabolism and collagen regeneration [8948-71], (2) Ms. Adi Schejter, Nairouz Farah, Shy Shoham, Technion-Israel Institute of Technology (Israel), Two-photon in vivo imaging of retinal microstructures [894875]. Dr. Deka from National Yang Ming University (Taiwan) was selected as the winner of the JenLab Young Investigator Award 2014.

For 14 years in a row, the conference organized poster awards for the students and postdoctoral fellows. The poster award was donated by all the conference sponsors including Becker \& Hickl, Boston Electronics, Chroma Technology, Coherent, ISS, NewportSpectra Physics, Princeton Instruments, Semrock, and Carl Zeiss.

The three poster award winners are

1. Leila B. Mostaco-Guidolin, National Research Council Canada (Canada), Shedding light into atherosclerosis: a quantitative study of nonlinear optical imaging in tracking plaque development [8948-74]

2. Ming Zhao, College of Optical Sciences, The University of Arizona (United States), Fast multiplexed time-resolved fluorescence microscopy for quantitative time-lapse FRET imaging in cells and deep tissue) [8948-90]

3. Brad Littleton, King's College London, United Kingdom Hyperspectral imaging via spectral interferometric polarised coherent anti-Stokes Raman scattering) [8948-101] 
Some of the most valuable contributions in this volume are articles written by highly experienced practitioners of multi-photon microscopy. They have enumerated the most important considerations in designing multi-photon microscopes and imaging experiments. Further, updates on the state-of-the-art commercial multi-photon microscope systems are presented. This volume also includes articles describing some recent advances in major multi-photon microscope components and applications including laser light sources, ultrafast optics, filters, FRET, FLIM, FCS, Raman, CARS, SRS and CRS microscopy and spectroscopy, single molecule, super-resolution imaging, endoscopy and various scientific and clinical applications.

On a personal note, the Conference Chairs are grateful for the participation of all authors, session chairs and acknowledge the innovation-driven manufacturers (Becker \& Hickl GmbH, Boston Electronics, Chroma Technology, Coherent, ISS, JenLab GmbH, NewportSpectra Physics, Princeton Instruments, Semrock, and Carl Zeiss) for their enthusiastic support in organizing this conference successfully for the last 14 years. We look forward to other exciting conferences in the second decade and welcome your continued participation and support.

\section{Ammasi Periasamy \\ Peter T. C. So \\ Karsten König}

